\title{
SPECIFIKA PRÁCE S BILINGVNÍM KLIENTEM V PSYCHOLOGICKÉ PRAXI
}

\author{
JURAJ JONÁŠ, MABEL RODRIGUEZ
}

\begin{abstract}
Abstrakt: V posledních letech je patrný nebývalý nárůst zájmu o výzkum bilingvizmu. $\mathrm{V}$ současné době již existuje mnoho teoretických poznatků $\mathrm{v}$ této oblasti, které se ale do psychologické praxe aplikují jen velice pozvolna. Cílem tohoto textu je přibližit současné poznání o vlivu bilingvizmu na kognici, emoce či osobnost, osvětlit některé kauzální neuropsychologické souvislosti a navrhnout některé postupy $\mathrm{k}$ efektivnějšímu př́stupu k bilingvním klientům či pacientům jak v oblasti pracovní psychologie, tak v klinické praxi. V úvodu jsou přiblížené současné teorie jazykového zpracování dvou jazyků jedním mozkem, což má pomoci vysvětlit některé další jevy, jako jsou kognitivní výhody bilingvizmu oproti monolingvizmu (jako jsou lepší exekutivní funkce či sociální kognice), ale také nevýhody (jako jsou obtíže ve verbálně zaměřených úkolech). Následující část textu se věnuje odlišnostem v osobnostních projevech či emocích na základě užití toho kterého jazyka. Dále jsou popsána specifika bilingvizmu u některých neuropsychiatrických onemocnění a poruch. Nakonec je stručně shrnuto několik poznámek k praktické aplikaci těchto poznatků $v$ psychologické praxi.
\end{abstract}

Klíčová slova: bilingvizmus, kognitivní funkce, neuropsychologie

\section{Specifics of working with a bilingual client in psychological practice}

Abstract: There has been a great increase of interest in bilingual studies in recent years. Currently there is a solid basis of theoretical knowledge in many aspects of bilingualism, however, they get to practicing psychologists only on a very limited scale. The goal of this article is to make this knowledge more accessible to practicing psychologists in both fields, clinical and I/O psychology. At the beginning, the contemporary theories of bilingual processing within one brain are discussed. They help to explain some aspects of bilingualism, such as cognitive advantages (like better executive functions, or social cognition) and disadvantages (like worse performance in verbal tasks). Then there are described differences in personality and emotional expressions based on the used language. This is followed by specifics of bilingualism in some neuropsychiatric conditions. The article concludes with several notes on practical application of mentioned research in psychological work.

Keywords: bilingualism, cognitive functions, neuropsychology

https://doi.org/10.14712/23366486.2020.9

\section{Úvod}

Již nějakou dobu se v literatuře objevují různé poznatky (více anebo méně přijímané) o tom, jaké důsledky má bilingvizmus na psychické funkce, anebo dokonce zdraví. Vzhledem k výše řečenému je bilingvizmus faktor, který vstupuje i do práce psychologa. 
Cílem tohoto článku je obeznámit praktikující psychology se základními poznatky vlivu bilingvizmu na poznání, prožívání a chování jedince, které by mu mohly pomoci v praxi. $\mathrm{Na}$ začátku budou uvedeny některé teoretické poznatky k zpracování informací bilingvními. To, jak se bilingvizmus projevuje na mozku, má pak důsledky na kognici, emoce a osobnost, což bude přiblíženo v další části tohoto textu. Také v případě některých neuropsychiatrických poruch mají bilingvní pacienti některá specifika oproti monolingvním protějškům se stejnou diagnózou, což je podstatné u posuzování klinického stavu pacienta. To vede k potřebě reflektovat tato specifika a klinickou rozvahu a hodnocení výsledků vyšetření je potřeba uzpůsobit.

U každého bilingvního lze jeden z jazyků identifikovat jako první, rodný (L1) a jeden jako druhý (L2, př́p. další jazyky L3, L4,...). Ačkoliv jednotná definice bilingvizmu není, a většina studií, které se tomuto tématu věnují, ani neuvádí, co pod tímto pojmem rozumí (jaká konkrétní jsou tedy vstupní kritéria subjektů), asi nejčastěji se pod bilingvizmem rozumí schopnost používat dva či více jazyků na každodenní bázi (Grosjean, 1994). Takto široce uchopená definice sice umožní provedení studií, ale bilingvizmus ovlivněn spoustou proměnných (jako je třeba věk akvizice L2, dosažená úroveň druhého jazyka, způsob akvizice L2, vzájemná vyváženost obou jazyků atd.) pak má za následek velkou variabilitu ve výzkumných datech. Dalšími faktory ovlivňujícími variabilitu výstupů studií na toto téma je rozdílný design výzkumů či to, že kombinace jazyků bilingvních se v různém pojetí liší, a strukturní rozdíly jazyků mohou také hrát významnou roli ve výstupu takovýchto studií.

\section{Zpracování vícero jazyků jedním mozkem}

Na zpracování všech jazyků bilingvního či monolingvního jedince se používá stejná mozková sít' (Wong, Yin, O’Brien, 2016). Základními centry jsou levý inferiorní frontální lalok (Brodmanova area, dále jen BA, 44 a 45 - Brockova oblast) a levý superiorní temporální lalok (kolem BA 22 - Wernickeova oblast) (obr. 1). Tyto oblasti jsou spojeny dorzální (superior longitudinal fasciculus a arcuate fasciculus) a ventrální dráhou nervových vláken (uncinate fasciculus a inferiorní fronto-okcipitální fasciculus) (Dick, Bernal, Tremblay, 2014; Friederici, Gierhan, 2013).

Brockova oblast byla původně spojována s porozuměním řeči, zatímco Wernickeho oblast s produkcí řeči, nicméně v současnosti bývá tento pohled zpochybňován (Poeppel, Hickok, 2004; Stowe, Haverkort, Zwarts, 2005; Tremblay, Dick, 2016). Spíše je v současné době Brockova oblast spojována s gramatickou a morfosyntaktickou složkou jazyka (Moro et al., 2001; Indefrey et al., 2001), zatímco Wernickeova oblast pravděpodobně zpracovává převážně lexikálně-sémantické jevy (Harpaz, Levkovitz, Lavidor, 2009). K podobnému (i když mnohem detailnějšímu) pohledu, a sice že temporální lalok souvisí spíše se zpracováním sémantické informace, zatímco frontální lalok převážně souvisí s exekucí jazyka, došly i veliké přehledy do té doby dostupné literatury (Price, 2010; Price, 2012). Tento pohled vedl některé autory k názoru, že gramatické jevy, protože jsou naučené spíše nevědomě, se vztahují k částem mozku, souvisejícím s procedurální pamětí (Brockovou oblastí), zatímco lexikálně-sémantické jevy, učené spíše vědomě, souvisí ponejvíce s oblastmi deklarativní paměti (Wernickeovou oblastí) (Ullman, 2004; Paradis, 2009; García, 2014). 


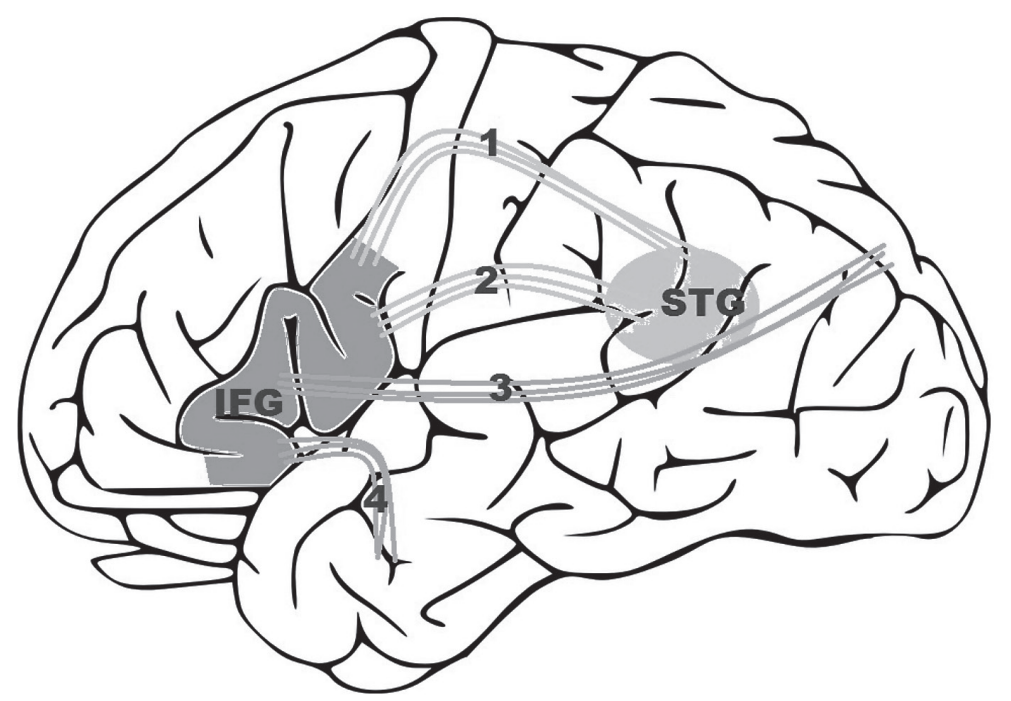

Obrázek 1 Jazyková sit'. Dvě základní oblasti, které slouži ke zpracování jazykové informace, jsou inferiorni frontálni lalok, neboli Brockova oblast (IFG) a superiorni temporálni lalok, neboli Wernickeova oblast (STG). Ty jsou propojeny dorzální dráhou (vyznačená světleji - vrchni dvě dráhy - arcuate fasciculus (1) a superior longitudinal fasciculus (2)) a ventrální dráhou (vyznačená tmavěji - spodní dvě dráhy - inferiorni fronto-okcipitálním fascikulus (3) a uncinate fascikulus (4)).

Jiný model (Memory-Unification-Control model MUC model, Hagroot, 2005; Hagroot 2013) vidí v různých částech mozku odlišnou fázi jazykového zpracování. Zatímco jsou znalosti fonologie, morfologie i syntaktických pravidel uchovány v levém temporálním laloku (tedy Wernickeově oblasti), dle tohoto modelu jsou tyto stavební bloky spojované, kombinované a modifikované do významových celků v levém prefrontálním kortexu (tedy Brockové oblasti a BA 6 a 47, oblastí ne výhradně dedikovaných jazyku, ale exekutivním operacím obecně). Tyto operace jsou koordinovány pomocí předního cingula (BA 24, 32, 33), tedy oblastí spojovanou s kognitivní kontrolou, a dalšími oblastmi prefrontální kůry (BA 46), která jazykový výstup propojí s kýženou akcí a sociálním kontextem.

Ačkoliv je uvedená sít' univerzální, existují jistá specifika, odvisející od strukturních vlastností daného jazyka. Třeba oproti uvedenému modelu zapojují čínští mluvčí během jazykového zpracování také pravý anteriorní temporální lalok, který je funkčně spojovaný se zpracováním tónu a tónové výšky (Ge et al., 2015). Každá slabika mluvené čínštiny disponuje jedním ze čtyř významotvorných tónů, kterými jsou jednotlivé slabiky intonovány. K podobným závěrům došly i jiné studie (Klein et al., 2006; Chee, Soon, Lee, 2003).

Funkční rozdělení je neuroanatomicky patrné především na úrovni organizace bílé hmoty do jednotlivých drah nervových vláken. Tak třeba dorzální proud souvisí spíše s artikulací, zatímco ventrální proud s porozuměním významu (Hickok, Poeppel, 2007; Fridriksson et al., 2016). Jiný model spíše spojuje dorzální dráhu s vnímáním a exekuci mluvené řeči a s komplexními syntaktickými operacemi, zatímco ventrální dráha se, dle tohoto pohledu, podílí na sémantickém zpracování a některých základních syntaktických 
úkolech (Friederici, Gierhan, 2013). Tyto dráhy neslouží výhradně na zpracování jazyka, ale podílí se i na jiných kognitivních funkcích (Vassal et al., 2016).

At’ už je platný kterýkoliv ze zmíněných modelů, podstatné je, že obě oblasti jsou funkčně jednotné, at' už mluvíme o kterémkoliv jazyku, a tedy u bilingvních jsou všechny jazyky jedince zpracovány funkčně jednotně. $Z$ toho vyplývá, že mozek nevytváří ostré hranice mezi jednotlivými jazyky. To pak vede $\mathrm{k}$ tomu, že oba jazyky bilingvního jsou aktivní po celou dobu užívání kteréhokoliv jazyka, a jazyk, který v daný moment není cílový, musí bilingvní aktivně potlačit (Green, 1998; Kroll et al., 2015). Tento psycholingvistický model paralelní aktivace vychází z experimentálních dat, nicméně s výše uvedenými neuroanatomickými modely jazykového zpracování konverguje. Tím pádem je třeba u bilingvních facilitováno zpracování kognátů (slov, které mají v obou jazycích stejný kořen i význam, jako třeba české „anděl“ a anglické ,angel“) (Costa, Caramazza, Sebastian-Galles, 2000; Dijkstra, 2005), zatímco zpracování interlingválních homografů (tedy slov se stejným kořenem, ale odlišným významem, jako třeba anglické „angel“, znamenající „anděl“ a holandské „angel“, co znamená „štípnutí“) podléhá interferenci v podobě větší chybovosti identifikování správného významu v daném jazyce, anebo delšího času potřebného ke správnému zpracování významu (Dijkstra, Van Heuven, 2002; van Heuven et al., 2008).

\section{Bilingvní se od monolingvních liší v kognici, emocích i osobnosti}

Co se kognice týče, asi nejčastěji se v souvislosti s bilingvizmem uvádí lepší výkon bilingvních oproti monolingvním v oblasti exekutivních funkcí (Bialystok, 2017; Valian, 2015). Zejména pak kognitivní kontrole, která se vysvětluje jako důsledek pravidelného potlačování necílového jazyka (inhibice) a přepínání jazykových kódů (Donnelly, Brooks, Homer, 2015). Meta-analýzy potvrzují také lepší výkon bilingvních v úkolech zaměřených na pracovní pamět' (Adesope et al., 2010; Grundy, Timmer, 2016). U bilingvních se také projevila lepší schopnost řešení problémů vhledem (Cushen, Wiley, 2011). Nicméně řada studií tento efekt bilingvizmu na exekutivní funkce nenašla, a někdy se relativně veliký podíl pozitivních výsledků $\mathrm{v}$ této oblasti interpretuje jako důsledek publikačního zkreslení (tedy důsledek toho, že je snazší publikovat pozitivní výsledky, než výsledky negativní), či př́ilišnou generalizaci specifických výstupů, navíc za použití rozdílné metodologie (De Bruin, Treccani, Della Sala, 2015; Paap, Johnson, Sawi, 2015). Meta-analýzy také dospěly k různým výsledkům. Některé ukazují, že dle dostupné literatury bilingvní skutečně určitým zlepšením exekutivních funkcí disponují (Adesope et al., 2010; Hilchey, Klein, 2011), jiné studie žádný signifikantní efekt bilingvizmu na exekutivní funkce nenašly (Lehtonen et al., 2018).

Bilingvizmus má také dopad na oblast sociální kognice. V nedávné meta-analýze se u bilingvních dětí ukázalo, že s lepší zvládnutou úrovní L2 se zlepšovala jejich schopnost teorie mysli (u vyšší úrovně L2 signifikantně vyšší než u monolingvních) (Schroeder, 2018).

U bilingvních se projevilo také několik kognitivních nevýhod, a sice jsou u nich pozorovány větší obtíže s verbální exekutivou. Zejména se mluví o menší slovní zásobě (Bialystok, Craik, Luk, 2012; Bialystok, Luk, 2012), nicméně je možné, že horší výkon bilingvních participantů v používaných testech těchto studií (Peabody Picture Vocabulary 
Test III) mohl být dán spíše jazykovou interferencí než tím, že by testovaní bilingvní měli skutečně menší slovní zásobu každého ze svých jazyků v porovnání s monolingvními. V souladu s tím lze vysvětlit také horší schopnost verbální fluence a menší přesnost a delší reakční čas u pojmenovávacích úkolů (pro přehled Bialystok, Craik, Luk, 2012). Tyto jevy lze pozorovat na úrovni postkonceptuálního zpracování jazyka, ale na úrovni klasifikace objektů a konceptualizace je výkon u bilingvních srovnatelný s monolingvními (Gollan et al., 2005).

Ve studiích, které se věnují emocionálnímu zpracování u bilingvních, panuje shoda, že u zpracování druhého jazyka dochází k emocionálnímu odcizení, vzdálení se (Pavlenko, 2012). To platí zejména pro jazyky, které bilingvní nabyl v pozdějším období života. Toto emocionální odcizení má pak vliv i na další funkce spojené s emocemi. Třeba u autobiografické paměti je větší počet vzpomínek dostupných v mateřském jazyce než v jazyce jiném (Schrauf, 2000), a také větší psychologická vzdálenost od konkrétního jazyka vede k tomu, že morální úsudky jsou utilitárnější než v jazyku blízkém (Costa et al., 2014). Také v cizím jazyce jsou morální úsudky méně striktní a participanti jsou si jimi méně jistí, a jsou shovívavější k porušení sociálních norem, jako je třeba lež (Geipel, Hadjichristidis, Surian, 2015). Také v jiném než rodném jazyce se u rozhodování jeví menší riziko, a posuzování rizika $\mathrm{v}$ různých situacích je konzistentnější, a také snižuje efekt klamu št'astné ruky (hot hand fallacy) (pro přehled Hayakawa et al., 2015).

Bilingvizmus má vliv dokonce na projevy osobnosti. Tak byly třeba pozorovány rozdíly v projevu extraverze (extraversion), př́větivosti (agreeableness) a svědomitosti (conscientiousness) u anglicko-španělských mluvčích (Ramírez-Esparza et al., 2006). U německo-španělských mluvčích skórovali probandi více u faktorů extraverze a neuroticizmu (neuroticism) v př́padě španělštiny, a přívětivosti $\mathrm{v}$ případě němčiny, a to bez ohledu na to, který z jazyků byl reportován jako mateřský (Veltkamp et al., 2012). Toto přepínání kulturních rámců (cultural frame switching) je vysvětlováno jako snaha o konzistentnost s kulturními normami daného jazykového kontextu (Ramírez-Esparza et al., 2006; Veltkamp et al., 2012). To třeba vede k tomu, že u sebeposuzovacích dotazníků bilingvní odpovídají v jednom ze svých jazyků jinak než ve druhém (Bond, Yang, 1982; Chen, Bond, 2010).

\section{Bilingvizmus a psychopatologie}

Projevy neuropsychiatrických onemocnění mají u bilingvních svá specifika. Tak se třeba afázie může týkat jednoho z jazyků více než druhého, halucinace či jiná psychotická symptomatologie se také u pacientů s touto symptomatikou liší na základě různých jazyků. Následující přehled stručně shrnuje dosavadní poznatky v této oblasti, nicméně publikovaných dat je zatím př́liš málo a klinický obraz příliš pestrý než abychom mohli dospět k ucelenějším závěrům o roli jazyka.

Afázie. Doposud největší studie bilingvních pacientů trpících afázií zahrnovala 20 pacientů (Fabbro, 2001). Z toho 65 \% trpělo paralelní afázií (oba jazyky jsou narušeny srovnatelně), u ostatních byla pozorována disociovaná afázie (profil afázie se u jednotlivých jazyků liší), prričemž u 20 \% sledovaných osob byl narušen L2, a u 15 \% L1. Všichni pacienti nabyli oba jazyky před sedmým rokem života a žádný prediktor (nejužívanější jazyk, momentální jazykový kontext, typ a umístění léze, typ afázie, anebo způsob naučení L2) se neukázal být dostatečně silný. 
Demence. U starší populace je patrná větší ochota k používání L1 než v dřivějších fázích života, nicméně v př́padě neurodegenerativních onemocnění mají bilingvní pacienti tendenci k regresi k L1 mnohem silnější (Ardila, 2017). První naučený jazyk bývá u Alzheimerovy nemoci méně narušený, a to pravděpodobně proto, že pamětové stopy vytvořené dříve deteriorují později než pamětové stopy novější (Mendez et al, 1999). U těchto pacientů je také častěji patrná jazyková interference (tedy užití slov, tvarů či větné stavby z jazyka, kterým právě není mluveno) a problém správné volby jazyka pro daný kontext (pro přehled Marini, Urgesi, Fabbro, 2012; Ardila, 2017), což pravděpodobně souvisí s oslabením schopnosti inhibovat neaktuální jazyk a snížením mentální flexibility. U Parkinsonovy nemoci jde o jev opačný, a sice těžkosti se syntaktickým zpracováním L1 a také s implicitními procedurálními gramatickými znalostmi (Zanini, Tavano, Fabbro, 2010). U bilingvizmu je v současnosti velice diskutovaná jeho neuroprotektivní schopnost. Řada studií totiž došla $\mathrm{k}$ závěru, že u bilingvních lidí dochází $\mathrm{k}$ neurodegenerativním onemocněním v průměru až o čtyři roky později než u populace monolingvní (pro přehled viz Guzmán-Vélez, Tranel, 2015; Perani, Abutalebi, 2015; Van den Noort et al., 2019). Předpokládá se, že díky bilingvizmu dochází ke kognitivní rezervě, což znamená, že některé oblasti jak šedé, tak bílé hmoty u bilingvních mají větší hustotu než u monolingvních, delší dobu trvá úbytek mozkové hmoty, než se projeví narušením kognice (Luk et al., 2011; Schweizer et al., 2011; Gold, Johnson, Powell, 2013; Abutalebi et al., 2015).

Neurovývojové poruchy. Nepravidelně praktikující klinici poukazují na rizika spojená s nesprávným učením druhého jazyka, jako jsou selektivní mutizmus, anebo na to, že může vést ke specifickým poruchám učení. Jediná dostupná přehledová studie, která shrnuje dosavadní poznatky k tomuto tématu, analyzovala výsledek 50 studií, které se týkají bilingvizmu a některých neurovývojových poruch (intelektového postižení, poruch komunikace, poruch autistického spektra, poruch pozornosti a hyperaktivity, specifických poruch učení, motorických a jiných poruch). Autoři této studie došli k závěru, že bilingvizmus nemá žádný negativní efekt na jazykový či psychický vývoj, naopak u jedinců trpících poruchami autistického spektra má bilingvizmus pozitivní dopad na komunikační a sociální fungování (Uljarević et al., 2016).

Psychózy. Jedním ze základních symptomů schizofrenie je i kognitivní narušení, které se může projevit také v oblasti verbální (Kim et al., 2015). Každý z jazyků může být poškozen do různé míry. Dokonce se v každém z jazyků může lišit i projevovaná míra symptomů (Hemphill, 1971), zejména se liší symptomatologie pozitivních symptomů (De Zulueta, Gene-Cos, Grachev, 2001). Co se halucinací týče, někteří autoři poukazují na halucinace pouze v L1 (Hemphill, 1971), zatímco jiní pouze v L2 (Malo Ocejo, Medrano, Uriarte, 1991), a další pozorují halucinace v obou jazycích (Lukianowicz, 1962; De Zulueta, Gene-Cos, Grachev, 2001; pro přehled Paradis, 2008). U halucinací v obou jazycích byly spíše pozorovány přátelské hlasy v rodném jazyce, a nepřátelské hlasy v L2 (Lukianowicz, 1962).

\section{Přístup k bilingvnímu klientovi}

Z výše uvedeného je patrné, že u psychologického vyšetření, at' už v oblasti pracovní psychologie, anebo v klinickém kontextu, je potřeba brát zřetel na to, že výsledky tohoto vyšetření budou u bilingvních lidí zkresleny, pokud toto vyšetření testovaný neabsolvuje 
v obou jazycích. Tak třeba u pacienta se sémantickou demencí nám může uniknout, že v jazyce, kterým právě netestujeme, může být narušení závažnější, a sice jen proto, že testujeme v pacientově mateřském jazyce (Mendez et al., 1999), anebo u pacientů se schizofrenií se nedozvíme komplexní kognitivní profil, pokud provedeme testování jen v jednom jazyce, protože třeba ve verbálních testech se jeho výkon může lišit (Rodriguez et al., 2015). To pak může vést $\mathrm{k}$ nesprávnému obrazu nemoci a nastavení remediací kognitivního deficitu.

Ze všeho nejdřív je potřeba vyhodnotit, zda klient či pacient skutečně bilingvní je, či nikoliv. To může být náročný úkol, protože, jak již bylo zmíněno, různá jazyková historie bilingvních způsobuje, že jsou jejich projevy nesmírně různorodé. Navíc ten, kdo mluví dvěma jazyky plynule, často ovládá alespoň částečně jazyk další. Definovat bilingvní na základě inkluzivních či exkluzivních kritérií proto spolehlivě nelze. K alespoň orientačnímu zmapování jazykové historie lze použít sadu otázek, které toho více napoví o tom, zda u daného člověka může mít bilingvizmus vliv na výsledky vyšetření či terapie (lze se inspirovat třeba u do češtiny zatím nepřeloženého Language History Questionaire LHQ 2.0, Li et al., 2014).

Pokud byl tedy vyšetřovaný identifikován jako bilingvní, bylo by ideální absolvovat vyšetření pokud možno v obou aktivních jazycích bilingvního testovaného. U afázií je potřeba zjištění míry deficitu v obou jazycích nevyhnutelná. K tomu byl vyvinut Billingual Aphasia Test (Paradis, 2011), který je aktuálně dostupný v češtině v kombinaci s angličtinou, němčinou, ruštinou, řečtinou a švédštinou. Nezbytnou podmínkou je nejen dostupnost testů v požadované jazykové variantě, ale také je potřeba, aby administrátor byl schopen tyto testy v daném jazyce administrovat, tedy aby byl sám bilingvní. Dále by měl mít dostatečné sociolingvistické kompetence, vážící se k jazykovým prostředím klienta a pokud to jazykové kompetence vyšetrujícího neumožňují, tak se doporučuje využít služeb profesionálního tlumočníka (Mindt et al., 2008).

Pokud to není možné, a musí být vyšetřen jenom jedním jazykem, tak je žádoucí pokusit se zabezpečit vyšetření v jeho mateřském jazyce. V tomto př́padě lze usuzovat na větší validitu vyšetření, pokud L1 a L2 u testovaného nedosáhly stejné úrovně.

Pokud žádná z předchozích možností není možná, tak lze vyšetření provést i v L2, ale s vědomím snížené validity tohoto testování. Na základě výše uvedených skutečností lze pak hypotetizovat na celkový stav, nicméně je potřeba mít na paměti, že k tomu, abychom tuto hypotézu ověřili, chybí data.

U psychoterapie hrozí při použití L2 emoční odcizení od sdělovaného obsahu (Marcos, 1976), o čemž svědčí i větší sklon a ochota klientů používat spíše L1 (Dewaele, 2015). Provádění terapie v L2 tedy může narušovat terapeutický proces, nicméně lze právě toto odtažení využít pro bezpečnější vstup k tématům, která klient může vnímat jako ohrožující (Byford, 2015).

\section{Závěr}

Cílem tohoto textu bylo přiblížit problematiku bilingvizmu praktikujícím psychologům. Základem toho, jak co možná nejefektivněji vyhodnocovat data pocházející z testů, jak interpretovat anebo vytvářet určitý terapeutický kontext, jsou co možná nepřesnější údaje o tom, jaký vliv má bilingvizmus na myšlení a prožívání. Je nicméně potřeba 
podtrhnout také roli kultury, která u bilingvních sehrává důležitou úlohu. Bilingvní bývají tím, že mají přístup ke dvěma jazykovým světům, často bikulturní (Marian, Kaushanskaya, 2004; Briley, Morris, Simonson, 2005). Jak bylo uvedeno výše, je to přepínání kulturních rámců, které ovlivňuje rozhodování či projevy osobnosti. Vyšetřující či terapii provádějící psycholog by si tedy měl být vědom vlastního kulturního přednastavení a vstupovat do kontaktu s klientem/pacientem bez kulturní předpojatosti (Cofresí, Gorman, 2004). Je samozřejmě otázkou, jak je v praxi možné brát zřetel na bilingvizmus, pokud tolik lidí mluví tolika různými jazyky. Nicméně pokud se k nám do ordinace či do assessment centra dostane k vyšetření osoba, u které lze předpokládat plynulou znalost více než jednoho jazyka, je potřeba mít na zřeteli, že výsledek vyšetření může být tímto zkreslen. Tento článek se snažil přiblížit, jakým způsobem.

Tato studie je výsledkem badatelské činnosti podporované projektem číslo LO1611 za finanční podpory MŠMT v rámci programu NPU.

\section{LITERATURA}

Abutalebi, J., Guidi, L., Borsa, V., Canini, M., Della Rosa, P. A., Parris, B. A., \& Weekes, B. S. (2015). Bilingualism provides a neural reserve for aging populations. Neuropsychologia, 69, 201-210.

Adesope, O. O., Lavin, T., Thompson, T., \& Ungerleider, C. (2010). A systematic review and meta-analysis of the cognitive correlates of bilingualism. Review of Educational Research, 80(2), 207-245.

Ardila, A. (2017). Dissociated language disorders in bilinguals. In A. Ardila, A Cieślicka, R. Heredia, M. Rossell (Eds.) Psychology of Bilingualism (pp. 211-224). Springer, Cham.

Bialystok, E. (2017). The bilingual adaptation: How minds accommodate experience. Psychological bulletin, 143(3), 233.

Bialystok, E., Craik, F. I., \& Luk, G. (2012). Bilingualism: consequences for mind and brain. Trends in cognitive sciences, 16(4), 240-250.

Bialystok, E., \& Luk, G. (2012). Receptive vocabulary differences in monolingual and bilingual adults. Bilingualism: Language and Cognition, 15(2), 397-401.

Bond, M. H., \& Yang, K. S. (1982). Ethnic affirmation versus cross-cultural accommodation: The variable impact of questionnaire language on Chinese bilinguals from Hong Kong. Journal of Cross-Cultural Psychology, 13(2), 169-185.

Briley, D. A., Morris, M. W., \& Simonson, I. (2005). Cultural chameleons: Biculturals, conformity motives, and decision making. Journal of Consumer Psychology, 15(4), 351-362.

Byford, A. (2015). Lost and gained in translation: The impact of bilingual clients' choice of language in psychotherapy. British Journal of Psychotherapy, 31(3), 333-347.

Cofresi, N. I., \& Gorman, A. A. (2004). Testing and assessment issues with Spanish-English bilingual Latinos. Journal of Counseling \& Development, 82(1), 99-106.

Costa, A., Caramazza, A., \& Sebastian-Galles, N. (2000). The cognate facilitation effect: implications for models of lexical access. Journal of Experimental Psychology: Learning, Memory, and Cognition, 26(5), 1283.

Costa, A., Foucart, A., Hayakawa, S., Aparici, M., Apesteguia, J., Heafner, J., \& Keysar, B. (2014). Your morals depend on language. PloS one, 9(4), e94842.

Cushen, P. J., \& Wiley, J. (2011). Aha! Voila! Eureka! Bilingualism and insightful problem solving. Learning and Individual Differences, 21(4), 458-462.

De Bruin, A., Treccani, B., \& Della Sala, S. (2015). Cognitive advantage in bilingualism: An example of publication bias?. Psychological science, 26(1), 99-107.

De Zulueta, F. I. S., Gene-Cos, N., \& Grachev, S. (2001). Differential psychotic symptomatology in polyglot patients: Case reports and their implications. British Journal of Medical Psychology, 74(3), 277-292.

Dewaele, J. M. (2015). From obscure echo to language of the heart: Multilinguals' language choices for (emotional) inner speech. Journal of Pragmatics, 87, 1-17. 
Dick, A. S., Bernal, B., \& Tremblay, P. (2014). The language connectome: new pathways, new concepts. The Neuroscientist, 20(5), 453-467.

Dijkstra, T. (2005). Bilingual visual word recognition and lexical access. In J. Kroll, A De Groot (Eds.) Handbook of bilingualism: Psycholinguistic approaches, (179-201). Oxford, New York: Oxford University Press.

Dijkstra, T., \& Van Heuven, W. J. (2002). The architecture of the bilingual word recognition system: From identification to decision. Bilingualism: Language and cognition, 5(3), 175-197.

Donnelly, S., Brooks, P. J., \& Homer, B. D. (2015, July). Examining the Bilingual Advantage on Conflict Resolution Tasks: A Meta-Analysis. In $\operatorname{CogSci}$.

Fabbro, F. (2001). The bilingual brain: Bilingual aphasia. Brain and language, 79(2), 201-210.

Fridriksson, J., Yourganov, G., Bonilha, L., Basilakos, A., Den Ouden, D. B., \& Rorden, C. (2016). Revealing the dual streams of speech processing. Proceedings of the National Academy of Sciences, 113(52), 15108-15113.

Friederici, A. D., \& Gierhan, S. M. (2013). The language network. Current opinion in neurobiology, 23(2), 250-254.

García, A. M. (2014). Neurocognitive determinants of performance variability among world-language users. Journal of World Languages, 1(1), 60-77.

Ge, J., Peng, G., Lyu, B., Wang, Y., Zhuo, Y., Niu, Z. \& Gao, J. H. (2015). Cross-language differences in the brain network subserving intelligible speech. Proceedings of the National Academy of Sciences, 112(10), 2972-2977.

Geipel, J., Hadjichristidis, C., \& Surian, L. (2015). How foreign language shapes moral judgment. Journal of Experimental Social Psychology, 59, 8-17.

Gold, B. T., Johnson, N. F., \& Powell, D. K. (2013). Lifelong bilingualism contributes to cognitive reserve against white matter integrity declines in aging. Neuropsychologia, 51(13), 2841-2846.

Gollan, T. H., Montoya, R. I., Fennema-Notestine, C. \& Morris, S. K. (2005). Bilingualism affects picture naming but not picture classification. Memory \& cognition, 33(7), 1220-1234.

Green, D. W. (1998). Mental control of the bilingual lexico-semantic system. Bilingualism: Language and cognition, 1(2), 67-81.

Grosjean, F. (1994). Individual bilingualism. In R. E. Asher, J. M. Y. Simpson (Eds.), The encyclopedia of language and linguistics, 3 (1656-1660). Oxford, New York: Pergamon Press.

Grundy, J. G., \& Timmer, K. (2017). Bilingualism and working memory capacity: A comprehensive meta-analysis. Second Language Research, 33(3), 325-340.

Guzmán-Vélez, E., \& Tranel, D. (2015). Does bilingualism contribute to cognitive reserve? Cognitive and neural perspectives. Neuropsychology, 29(1), 139.

Hagoort, P. (2005). On Broca, brain, and binding: a new framework. Trends in cognitive sciences, 9(9), 416-423.

Hagoort, P. (2013). MUC (memory, unification, control) and beyond. Frontiers in psychology, 4, 416.

Harpaz, Y., Levkovitz, Y., \& Lavidor, M. (2009). Lexical ambiguity resolution in Wernicke's area and its right homologue. Cortex, 45(9), 1097-1103.

Hayakawa, S., Costa, A., Foucart, A., \& Keysar, B. (2016). Using a foreign language changes our choices. Trends in Cognitive Sciences, 20(11), 791-793.

Hemphill, R. E. (1971). Auditory hallucinations in polyglots. South African Medical Journal, 45(12).

Hickok, G., \& Poeppel, D. (2007). The cortical organization of speech processing. Nature reviews neuroscience, 8(5), 393.

Hilchey, M. D., \& Klein, R. M. (2011). Are there bilingual advantages on nonlinguistic interference tasks? Implications for the plasticity of executive control processes. Psychonomic bulletin \& review, 18(4), 625-658.

Chee, M. W., Soon, C. S., \& Lee, H. L. (2003). Common and segregated neuronal networks for different languages revealed using functional magnetic resonance adaptation. Journal of Cognitive Neuroscience, 15(1), 85-97.

Chen, S. X., \& Bond, M. H. (2010). Two languages, two personalities? Examining language effects on the expression of personality in a bilingual context. Personality and Social Psychology Bulletin, 36(11), 1514-1528.

Indefrey, P., Hagoort, P., Herzog, H., Seitz, R. J., \& Brown, C. M. (2001). Syntactic processing in left prefrontal cortex is independent of lexical meaning. Neuroimage, 14(3), 546-555.

Kim, S. J., Shim, J. C., Kong, B. G., Kang, J. W., Moon, J. J., Jeon, D. W. \& Jung, D. U. (2015). The relationship between language ability and cognitive function in patients with schizophrenia. Clinical Psychopharmacology and Neuroscience, 13(3), 288.

Klein, D., Zatorre, R. J., Chen, J. K., Milner, B., Crane, J., Belin, P., \& Bouffard, M. (2006). Bilingual brain organization: A functional magnetic resonance adaptation study. Neuroimage, 31(1), 366-375. 
Kroll, J. F., Dussias, P. E., Bice, K., \& Perrotti, L. (2015). Bilingualism, mind, and brain. Annu. Rev. Linguist., 1(1), 377-394.

Lehtonen, M., Soveri, A., Laine, A., Järvenpää, J., de Bruin, A., \& Antfolk, J. (2018). Is bilingualism associated with enhanced executive functioning in adults? A meta-analytic review. Psychological bulletin, 144(4), 394.

Li, P., Zhang, F., Tsai, E., \& Puls, B. (2014). Language history questionnaire (LHQ 2.0): A new dynamic web-based research tool. Bilingualism: Language and Cognition, 17(3), 673-680.

Luk, G., Bialystok, E., Craik, F. I., \& Grady, C. L. (2011). Lifelong bilingualism maintains white matter integrity in older adults. Journal of Neuroscience, 31(46), 16808-16813.

Lukianowicz, N. (1962). Auditory hallucinations in polyglot subjects. European Neurology, 143(4), 274-294.

Malo Ocejo, P., Medrano, J. A., \& Uriarte, J. U. (1991). Auditory hallucinations in bilingual subjects. Archivos de neurobiologia, 54(1), 15-19.

Marcos, L. R. (1976). Bilinguals in psychotherapy: Language as an emotional barrier. American journal of Psychotherapy, 30(4), 552-560.

Marian, V., \& Kaushanskaya, M. (2004). Self-construal and emotion in bicultural bilinguals. Journal of Memory and Language, 51(2), 190-201.

Marini, A., Urgesi, C., \& Fabbro, F. (2012). Clinical neurolinguistics of bilingualism. The Handbook of the Neuropsychology of Language, 2, 738-759.

Mendez, M. F., Perryman, K. M., PontÓn, M. O., \& Cummings, J. L. (1999). Bilingualism and dementia. The Journal of neuropsychiatry and clinical neurosciences, 11(3), 411-412.

Mindt, M. R., Arentoft, A., Germano, K. K., D’Aquila, E., Scheiner, D., Pizzirusso, M. \& Gollan, T. H. (2008). Neuropsychological, cognitive, and theoretical considerations for evaluation of bilingual individuals. Neuropsychology review, 18(3), 255-268.

Moro, A., Tettamanti, M., Perani, D., Donati, C., Cappa, S. F., \& Fazio, F. (2001). Syntax and the brain: disentangling grammar by selective anomalies. Neuroimage, 13(1), 110-118.

Paap, K. R., Johnson, H. A., \& Sawi, O. (2015). Bilingual advantages in executive functioning either do not exist or are restricted to very specific and undetermined circumstances. Cortex, 69, 265-278.

Paradis, M. (2008). Bilingualism and neuropsychiatric disorders. Journal of Neurolinguistics, 21(3), 199-230.

Paradis, M. (2009). Declarative and procedural determinants of second languages (Vol. 40). John Benjamins Publishing.

Paradis, M. (2011). Principles underlying the Bilingual Aphasia Test (BAT) and its uses. Clinical linguistics \& phonetics, 25(6-7), 427-443.

Pavlenko, A. (2012). Affective processing in bilingual speakers: Disembodied cognition?. International Journal of Psychology, 47(6), 405-428.

Perani, D., \& Abutalebi, J. (2015). Bilingualism, dementia, cognitive and neural reserve. Current opinion in neurology, 28(6), 618-625.

Poeppel, D., \& Hickok, G. (2004). Towards a new functional anatomy of language. Cognition 92 (1-2), 1-12.

Price, C. J. (2010). The anatomy of language: a review of $100 \mathrm{fMRI}$ studies published in 2009. Annals of the new York Academy of Sciences, 1191(1), 62-88.

Price, C. J. (2012). A review and synthesis of the first 20 years of PET and fMRI studies of heard speech, spoken language and reading. Neuroimage, 62(2), 816-847.

Ramírez-Esparza, N., Gosling, S. D., Benet-Martínez, V., Potter, J. P., \& Pennebaker, J. W. (2006). Do bilinguals have two personalities? A special case of cultural frame switching. Journal of research in personality, 40(2), 99-120.

Rodriguez, M., Kratochvilova, Z., Kuniss, R., Vorackova, V., Dorazilova, A., \& Fajnerova, I. (2015). Case report: Is verbal cognitive performance in bilingual neuropsychiatric patients test-language dependent?. PsyCh journal, 4(4), 208-217.

Schrauf, R. W. (2000). Bilingual autobiographical memory: Experimental studies and clinical cases. Culture \& Psychology, 6(4), 387-417.

Schroeder, S. R. (2018). Do bilinguals have an advantage in theory of mind? A meta-analysis. Frontiers in Communication, $3,36$.

Schweizer, T. A., Ware, J., Fischer, C. E., Craik, F. I., \& Bialystok, E. (2012). Bilingualism as a contributor to cognitive reserve: Evidence from brain atrophy in Alzheimer's disease. Cortex, 48(8), 991-996.

Stowe, L. A., Haverkort, M., \& Zwarts, F. (2005). Rethinking the neurological basis of language. Lingua, 115(7), 997-1042. 
Tremblay, P., \& Dick, A. S. (2016). Broca and Wernicke are dead, or moving past the classic model of language neurobiology. Brain and language, 162, 60-71.

Uljarević, M., Katsos, N., Hudry, K., \& Gibson, J. L. (2016). Practitioner Review: Multilingualism and neurodevelopmental disorders-an overview of recent research and discussion of clinical implications. Journal of Child Psychology and Psychiatry, 57(11), 1205-1217.

Ullman, M. T. (2004). Contributions of memory circuits to language: The declarative/procedural model. Cognition, 92(1-2), 231-270.

Valian, V. (2015). Bilingualism and cognition. Bilingualism: Language and Cognition, 18(1), 3-24.

Van den Noort, M., Vermeire, K., Bosch, P., Staudte, H., Krajenbrink, T., Jaswetz, L. \& Lee, S. H. (2019). A systematic review on the possible relationship between bilingualism, cognitive decline, and the onset of dementia. Behavioral Sciences, 9(7), 81.

Van Heuven, W. J., Schriefers, H., Dijkstra, T., \& Hagoort, P. (2008). Language conflict in the bilingual brain. Cerebral cortex, 18(11), 2706-2716.

Vassal, F., Schneider, F., Boutet, C., Jean, B., Sontheimer, A., \& Lemaire, J. J. (2016). Combined DTI tractography and functional MRI study of the language connectome in healthy volunteers: extensive mapping of white matter fascicles and cortical activations. PloS one, 11(3), e0152614.

Veltkamp, G. M., Recio, G., Jacobs, A. M., \& Conrad, M. (2013). Is personality modulated by language?. International Journal of Bilingualism, 17(4), 496-504.

Wong, B., Yin, B., \& O'Brien, B. (2016). Neurolinguistics: Structure, function, and connectivity in the bilingual brain. BioMed research international, 2016.

Zanini, S., Tavano, A., \& Fabbro, F. (2010). Spontaneous language production in bilingual Parkinson's disease patients: evidence of greater phonological, morphological and syntactic impairments in native language. Brain and Language, 113(2), 84-89.

Mgr. Bc. Juraj Jonášs, Univerzita Karlova, Filozofická fakulta, katedra psychologie, Národní ústavduševního zdraví, e-mailJuraj.Jonas@nudz.cz

PhDr. Mabel Rodriguez, Ph.D., Univerzita Karlova, Filozofická fakulta, katedra psychologie, Národní ústavduševniho zdravi, e-mail mabel.rodriguez@nudz.cz 